\section{Vol. 68, No. 45}

In the report "Evaluation of Bronchoalveolar Lavage Fluid from Patients in an Outbreak of E-cigarette, or Vaping, Product Use-Associated Lung Injury - 10 States, August-October 2019" names of the members of the Lung Injury Response Team and persons in Acknowledgments were omitted. The names are included below.

Benjamin C. Blount, $\mathrm{PhD}^{1, *}$; Mateusz P. Karwowski, MD ${ }^{1, *}$; Maria Morel-Espinosa, $\mathrm{PhD}^{1}$; Jon Rees, $\mathrm{PhD}^{1}$; Connie Sosnoff, $\mathrm{MA}^{1}$; Elizabeth Cowan, $\mathrm{PhD}^{1}$; Michael Gardner, $\mathrm{MS}^{1}$; Lanqing Wang, $\mathrm{PhD}^{1}$; Liza Valentin-Blasini, $\mathrm{PhD}^{1}$; Lalith Silva, $\mathrm{PhD}^{1}$; Víctor R. De Jesús, $\mathrm{PhD}^{1}$; Zsuzsanna Kuklenyik, $\mathrm{PhD}^{1}$; Cliff Watson, $\mathrm{PhD}^{1}$; Tiffany Seyler, $\mathrm{PhD}^{1}$; Baoyun Xia, $\mathrm{PhD}^{1}$; David Chambers, $\mathrm{PhD}^{1}$; Peter Briss, $\mathrm{MD}^{2}$; Brian A. King, $\mathrm{PhD}^{3}$; Lisa Delaney, $\mathrm{MS}^{4}$; Christopher M. Jones, PharmD, DrPH ${ }^{5}$; Grant T. Baldwin, $\mathrm{PhD}^{6}$; John R. Barr, $\mathrm{PhD}^{1}$; Jerry Thomas, $\mathrm{MD}^{1}$; James L. Pirkle, MD, $\mathrm{PhD}^{1}$; Lung Injury Response Team

\begin{abstract}
${ }^{1}$ Division of Laboratory Sciences, National Center for Environmental Health, CDC; ${ }^{2}$ Office of the Director, National Center for Chronic Disease Prevention and Health Promotion, CDC; ${ }^{3}$ Office on Smoking and Health, National Center for Chronic Disease Prevention and Health Promotion, CDC; ${ }^{4}$ Office of the Director, National Institute for Occupational Safety and Health, CDC; ${ }^{5}$ Office of Strategy and Innovation, National Center for Injury Prevention and Control, CDC; ${ }^{6}$ Division of Overdose Prevention, National Center for Injury Prevention and Control, CDC.
\end{abstract}

*These two authors contributed equally.

\section{Acknowledgments}

From outside affiliates: Peter Shields, Ohio State University; Doug Heitkemper, Duane Satzger, Rachael Schmidt, Food and Drug Administration; Scott Becker, Eric Blank, Julianne Nassif, Association of Public Health Laboratories, Silver Spring, Maryland; Meshel Lange, Jon Meiman, Ian Pray, Noel Stanton, Wisconsin Department of Health Services; Kathleen Attfield, Jeff Fowles, Nicole Green, California Department of Public Health; Diane Noel, Connecticut Department of Public Health; Katherine A. Kelley, Connecticut State Public Health Laboratory; Sydney Jones, CDC/Connecticut Department of Public Health; EVALI staff members at the Hawaii Department of Health; Matt Charles, Carlos Morales, Mohammad S. Nasir, Illinois Department of Public Health Laboratory; David Blythe, Kenneth Feder, Cliff Mitchell, Maryland Department of Health; Matt Bashore, Rita Seith, Eden Wells, Michigan Department of Health and Human Services; Cory Cole, Paige D'Heilly, Kaila Hanson, Stacy Holzbauer, Mark Lunda, Ruth Lynfield, Jason Peterson, Stefan Saravia, Terra Wiens, Matt Wogen, Minnesota Department of Health; Emily Hall, Varun Shetty, Texas Department of State Health Services; Jackie Patel, Utah Department of Health; Robert Blount, Alejandro Comellas, University of Iowa; David Spink, New York State Department of Health, Wadsworth Center.
From CDC: Kelly Ally, Stephen Arnstein, Doris Ash, Thomas Blake, William Bragg, Martha Braselton, Roberto Bravo, Melissa Carter, Charles Chambers, Joseph Corstvet, Abbey Doyle, Ryan Favors, Nathalie Gonzalez-Jimenez, Naudia Gray, Tonya Guillot, Beth Hamelin, Bryan Hearn, Alan Holder, Sam Isenberg, Leslie Jarchow, Ashley Jones, Logan Krajewski, Cassandra Kyle, Erica Lewis, Joseph Lisko, Howard Liverance, Megan McGuigan, Magaly Mendez, Mike Mojica, Stephanie Negrete, Karen Rivera Nieves, Wellington Onyenwe, Nick Pahno, Steve Pappas, Jose Perez, Chris Pittman, Andrew Puetz, Mike Rollins, Sina De Leon Salazar, Chariety Sapp, Becky Shaner, Karen Shields, Mitchell Smith, Tonya Tuberville, Erin Wade, Rebekah Warton, Amy Watson, Andrew Wilmore, Joe Wooten, Division of Laboratory Sciences, National Center for Environmental Health, CDC; Stephanie Kerr, Division of Performance Improvement and Field Services, Center for State, Tribal, Local, and Territorial Support; Althea Grant, Office of the Director for Non-Infectious Diseases, CDC; Alberto Santana, Shannon Woodward, Mary E. Evans, National Center for Injury Prevention and Control, CDC; Nicole Elliott, Michelle O'Hegarty, Josh Petty, National Center for Chronic Disease Prevention and Health Promotion, CDC; Megan O'Sullivan, Sarah Kabbani, Sarah Reagan-Steiner, National Center for Emerging and Zoonotic Infectious Diseases, CDC; Stefanie Erskine, Susan Hocevar Adkins, National Center for HIV/Aids, Viral Hepatitis, STD, and TB Prevention, CDC; Karen Hunter, National Center on Birth Defects and Developmental Disabilities, CDC; Ibad Khan, Center for Preparedness and Response, CDC; Joann Kang, Tara C. Jatlaoui, Emily H. Koumans, Jennifer L. Wiltz, Paul Melstrom, National Center for Chronic Disease Prevention and Health Promotion, CDC; Michele Montandon, Center for Global Health, CDC; David Weissman, National Institute for Occupational Safety and Health, CDC.

\section{Lung Injury Response Team}

Christina Brosius, Kevin Caron, Carolina Fernandez, Cory Holder, Rudy Johnson, Cody Newman, Chris Reese, Denise Tevis, Division of Laboratory Sciences, National Center for Environmental Health, CDC; Dana Meaney Delman, Kara Polen, Division of Birth Defects and Infant Disorders, National Center on Birth Defects and Developmental Disabilities, CDC; Anita Patel, National Center for Immunization and Respiratory Diseases, CDC; Bobby N. Brewer, Battelle Memorial Institute, Columbus, Ohio; Macarena Garcia, Center for Surveillance, Epidemiology, and Laboratory Services, CDC; Ian Williams, National Center for Emerging and Zoonotic Infectious Diseases, CDC; Kevin Chatham-Stephens, National Center on Birth Defects and Developmental Disabilities, CDC; Jennifer Freed, Division of Community Health Investigations, Agency for Toxic Substances and Disease Registry; Donald Hayes, Matt Ritchey, National Center for Chronic Disease Prevention and Health Promotion, CDC. 